\title{
The Case for On-Line College Education - a work in progress
}

\section{Dr. Brian E. White, CAU-SES}

Brian E. White received Ph.D. and M.S. degrees in Computer Sciences from the University of Wisconsin, and S.M. and S.B. degrees in Electrical Engineering from M.I.T. He served in the United States Air Force, and for 8 years was at M.I.T. Lincoln Laboratory. For five years Dr. White was a principal engineering manager at Signatron, Inc. In his 28 years at The MITRE Corporation, he held a variety of senior professional staff and project/resource management positions. He was Director of MITRE's Systems Engineering Process Office, 2003-2009. Dr. White left MITRE in July, 2010, to offer a consulting service, CAU-SES ("Complexity Are Us" - Systems Engineering Strategies).

\section{Dr. S. Jimmy Gandhi, California State University, Northridge}

S. Jimmy Gandhi is currently an assistant professor in the Manufacturing Systems Engineering \& Management (MSEM) Department at California State University, Northridge. He teaches courses in quality management, entrepreneurship and systems engineering. Prior to coming to Cal State, he was with the School of Systems and Enterprises at Stevens Institute of Technology and also taught at the Zicklin School of Business at Baruch College, which is part of the City University of New York (CUNY). Dr. Gandhi has research interests in the fields of globalization, risk management and sustainability. He is an active member of ASEM, ASEE and participates in their conferences on a yearly basis. He has a Ph.D. in Engineering Management from Stevens Institute of Technology, a M.S. in Engineering Management from California State University, Northridge and a B.S. in Engineering from Illinois Institute of Technology. 


\title{
The Case for Online College Education - a work in progress
}

\begin{abstract}
Going to college, often means incurring exorbitant tuition and high living costs, for students. This has become largely unaffordable for many aspirants, and results in otherwise qualified students, not getting a higher education. As part of this effort and future papers, the authors are working on developing various models of online college education with a credible (to be defined and discussed) certificate of completion or degree and are evaluating the extent to which each of those models are viable future possibilities that could help such students. The primary benefit would be to greatly increase the likelihood of productive adult lives without having to attend onsite college classes. Admittedly, at present the more realistic online education opportunities are tuition-based (rather than free) alternatives that lead to either a certificate or degree. With today's internet technology and social networking capabilities, it seems feasible to provide superior educational opportunities for a much larger and more diverse population of people. The online medium is not only a venue for educational innovation through experimental teaching methods, but also a source of new information (e.g., through online surveys and tracking of student progress). Online experiences should lead to further improvements in modern educational techniques and methods. This and subsequent papers will explore the viability of these notions while concentrating on several online education scenarios through: 1) further elaboration (particularly, within two specific domains, viz., engineering leadership/project management, and career/business education); 2) the gathering and reporting of supporting data; 3) the application of relevant fundamentals from complexity theory; and 4) stimulating analogies about complex system behaviors and complex systems engineering principles. All this may influence a positive transformation in the "mindsights" of aspirants, students, teachers, professors, and college/university educators.
\end{abstract}

\section{Introduction}

This paper was initially conceived to evaluate the feasibility of free online education in enhancing anyone's ability to establish their desired career while easing the requisite financial burden of having to go to college. This problem often arises either because of high tuition and living costs or burdensome loans that follow graduates long into their careers. Furthermore, many college graduates cannot even find jobs in their major field. This can be the result of a sluggish economy or employers looking for career skills that were not really taught and learned in college. Thus, the authors started pondering ways online education could help alleviate these dilemmas. There are various challenges that need to be considered not the least of which is the credibility offered to online programs. A large part of our society still believes, "You get what you pay for.", and considering that underlying psychology, it will be a challenge for employers to hire people with free online educations. Perhaps the most fundamental question to be answered for free online education is: How much can employers measure and trust the real learning and practical knowledge that online students have acquired?

As part of this work in progress, the authors presently assert that free online education leading to a certificate or a degree may be too ambitious goals. In this continuing study, the authors consider less ambitious models that include paying for online education, but at reduced rates. The expected online benefits would be lower total educational costs (reduced tuition fees and 
savings on campus living and/or commuting expenses). Furthermore, students interested in pursuing hybrid situations could take online courses elsewhere if the tuition rate charged for online education at their home school is significantly higher than its on-campus education. ${ }^{1}$

The current state of online education will be summarized in this paper to establish a platform on which to build possibilities for improvement. Several university educators recognize that: 1) massive online education is the wave of the future; ${ }^{2}$ ) our understanding of how people learn will be greatly enhanced by the online experience; ${ }^{3}$ and 3 ) the role of colleges and universities could be significantly altered. ${ }^{3}$

The authors' research so far shows that there are two prestigious U.S. universities that have each invested \$30M in online education. The authors have already postulated (and will continue researching) why these universities choose to do this and how they plan to recoup these investments. Currently, the authors hypothesize that their return on investment must be more than simply enhancing their already outstanding reputations and attracting even more qualified students. There could be other ways of recovering this investment, by charging for completion certificates, student testing, and certain forms of advertising on online pages, e.g., as is currently practiced by many web site providers. Moreover, once tuition is charged for online offerings, schools could charge much less than normal but with many more students, they could reap much greater revenues than for on-campus learning. Thus economies of scale could be built into the online education model. Clearly, a primary concern of these institutions is not to cheapen education albeit while making it more affordable. They must also be concerned with convincing potential students that the quality of online education can be at least as valuable as a traditional college education, even if the online variety costs less.

In making a good case for online education, a range of possibilities must be discussed. Five actual or possible future alternatives of online education, with perhaps distinct and nuanced scenarios (indexed by 1, 2a, 2b, 3a, 3b, 4a, 4b, 5a, and 5b below) will be considered. These will cover a spectrum of online education scenarios (associated with a variety of costs and benefits) from some scenarios that are already underway to those that currently do not exist.

1. Tuition free to students - more for those who have true interest in the subject matter and can demonstrate a reason to be enrolled in such a program through their statement of purpose, e.g., retirees lifelong learners, and young people just starting out

2. Tuition free to students - Leading to credible certification of completion

a. No student payback

b. Students payback later

3. Tuition free to students - Leading to degree

a. No student payback

b. Students payback later

4. Not tuition free to students - Leading to credible certification of completion

a. No student loans incurred

b. Student loans incurred

5. Not tuition free to students - Leading to degree

a. No student loans incurred

b. Student loans incurred 
Some up-front explanation about Alternatives $2 \mathrm{~b}$ and $3 \mathrm{~b}$ is in order: Student payback later includes the possibility that students will only reimburse the providers of their online education if they actually acquire a job, position, and/or career appropriate for the training they were offered online, and only after they have managed to accumulate the resources to do so. This is possible in Australia, for example. But for the purpose of this paper, scenarios $2 \mathrm{a}$ and $2 \mathrm{~b}$ will be considered together as Scenario 2, and Scenarios 3a and 3b will be considered together as Scenario 3.

As a first step in the authors' quest to research this whole range of alternatives, the focus of this paper is only on Scenarios 1, 2, and 3. This simplifies the present discussion and provides additional time to gather enough data to adequately discuss other alternatives in forthcoming papers.

\section{Summary of Current Status}

Before presenting any details and analyses of the current situation, here are the authors' assessments of the current relative viability of the above proposed five instances of online education. We have chosen a color code, as depicted in the last column of Table 1 shown below. The definitions of the colors are as follows.

Blue: Not only presently possible but ongoing and thriving.

Purple: Not presently possible and quite difficult to achieve, particularly with respect to establishing suitable testing and credible certificates.

Red: Not presently possible and even more difficult to achieve, particularly with respect to providing professors, examinations, and degrees.

Yell囚W: Presently possible depending on amount of tuition supporting testing and certifications but somewhat unlikely because of avoiding loans.

Brown: Presently possible depending on amount of tuition supporting testing and certifications.

Gray: Presently possible depending on amount of tuition supporting examination and degrees but somewhat unlikely because of avoiding loans.

Green: Presently possible depending on amount of tuition supporting examination and degrees.

Table 1. Authors' Assessment of Present Viability of Online Educational Options

\begin{tabular}{|c|c|c|c|c|c|c|c|c|c|c|c|}
\hline \multirow[b]{2}{*}{ Scenario } & \multirow[b]{2}{*}{ Clientele } & \multirow[b]{2}{*}{ Purpose } & \multicolumn{3}{|c|}{ Cost to Clientele } & \multirow[b]{2}{*}{$\begin{array}{l}\text { Savings to } \\
\text { Participant }\end{array}$} & \multirow[b]{2}{*}{ Credential } & \multicolumn{3}{|c|}{ Cost to Provider } & \multirow[b]{2}{*}{$\begin{array}{c}\text { Present } \\
\text { Assessment }\end{array}$} \\
\hline & & & \begin{tabular}{|c|} 
Internet \\
Equipage
\end{tabular} & Tuition & Loan & & & $\begin{array}{c}\text { Web } \\
\text { Site } \\
\text { Offerin }\end{array}$ & Facilitator & Other & \\
\hline 1 & Anyone & Fun & Yes & No & N/A & N/A & None & Yes & Optional & None & Blue \\
\hline 2 & \begin{tabular}{|l} 
Students \\
\end{tabular} & Career Learning & Yes & No & N/A & Time; Commuting & Credible Certificate & Yes & Teacher & Testing & Purple \\
\hline 3 & Students & Career Learning & Yes & No & N/A & Time; Commuting & Degree & Yes & Professor & Examination & Red \\
\hline $4 \mathrm{a}$ & Students & Career Learning & Yes & Yes & No & Time; Commuting & Credible Certificate & Yes & Teacher & Testing & Yellow \\
\hline $4 \mathrm{~b}$ & \begin{tabular}{|l} 
Students \\
\end{tabular} & Career Learning & Yes & Yes & Yes & Time; Commuting & Credible Certificate & Yes & Teacher & Testing & Brown \\
\hline $5 \mathrm{a}$ & \begin{tabular}{|l} 
Students \\
\end{tabular} & Career Learning & Yes & Yes & No & Time; Commuting & Degree & Yes & Professor & Examination & Gray \\
\hline $5 b$ & Students & Career Learning & Yes & Yes & Yes & Time; Commuting & Degree & Yes & Professor & Examination & Green \\
\hline
\end{tabular}

This table will be revisited, generalized, and updated in the future as the authors perform additional research work. 


\section{Tier I Colleges/Universities Offering Courses}

The most notable provider of free online courses is arguably edX which was started by MIT and funded by MIT and Harvard. The MIT Technology Review article of November/December 2012 is a most comprehensive and cogent article on the subject of higher education. There a healthy degree of skepticism is about the future for online learning is expressed but its prospects appear to be quite encouraging. ${ }^{3}$

Another major free online course provider is Coursera. ${ }^{4}$ Some other elite institutions backing online education include the University of California at Berkeley, Georgetown University, ${ }^{5}$ and the University of Texas, ${ }^{6}$ Oxford, ${ }^{4}$ Wellesley, ${ }^{7,8}$ the University of Michigan, ${ }^{9}$ Duke University, Johns Hopkins University, and the University of Virginia. ${ }^{10}$

The MIT Technology Review article also contains a table summarizing several e-institutions' (edX, Udacity, Coursera, Open Learning Initiative, University of Phoenix, and The Open University) online education efforts, including year Founded, number of Enrollees, Model (for profit or nonprofit), and Details columns. ${ }^{3}$

As shown in Table 2, edX and Coursera courses cannot be taken for credit. However, a certificate of completion can be obtained for a modest fee. Further research is needed to determine this modest fee, investments of other schools, and to resolve other missing or unknown (unk) entries.

Table 2. Information Regarding Tier I Universities

\begin{tabular}{|c|c|c|c|c|c|c|}
\hline Institution & Provider & Domain(s) & Credentials & Fees & Investment & Comment \\
\hline MIT & edX & Engineering & No Credit & Free & $\$ 30 \mathrm{M}$ & Math; unk \\
\hline Harvard & edX & & No Credit & Free & $\$ 30 \mathrm{M}$ & math?; unk \\
\hline Berkeley & $\begin{array}{l}\text { edX/ } \\
\text { Coursera }\end{array}$ & $\begin{array}{l}\text { Engineering/ } \\
\text { Liberal Arts }\end{array}$ & No Credit & Free & unk & $\begin{array}{l}\text { math, com- } \\
\text { puter science } \\
\text { to public } \\
\text { health to poet- } \\
\text { ry?; unk }\end{array}$ \\
\hline Georgetown & edX & Liberal Arts & No Credit & Free & unk & \\
\hline U. Texas & edX & Engineering & No Credit & Free & unk & math?; unk \\
\hline Stanford & $\begin{array}{l}\text { edX/ } \\
\text { Coursera }\end{array}$ & Engineering & No Credit & Free & unk & $\begin{array}{l}\text { math, com- } \\
\text { puter science } \\
\text { to public } \\
\text { health to poet- } \\
\text { ry?; unk }\end{array}$ \\
\hline Cal Tech & unk & $\begin{array}{l}\text { Engineering/ } \\
\text { Science }\end{array}$ & unk & unk & unk & unk \\
\hline Oxford & unk & Liberal Arts & unk & unk & unk & unk \\
\hline Princeton & Coursera & $\begin{array}{l}\text { Engineering/ } \\
\text { Liberal Arts }\end{array}$ & unk & unk & unk & $\begin{array}{l}\text { computer sci- } \\
\text { ence to public } \\
\text { health to poet- } \\
\text { ry?; unk }\end{array}$ \\
\hline
\end{tabular}




\begin{tabular}{|l|l|l|l|l|l|l|}
\hline Wellesley & edX & Liberal Arts & No Credit & Free & unk & unk \\
\hline Penn & Coursera & $\begin{array}{l}\text { Engineering/ } \\
\text { Liberal Arts }\end{array}$ & unk & unk & unk & $\begin{array}{l}\text { computer sci- } \\
\text { ence to public } \\
\text { health to poet- } \\
\text { ry?; unk }\end{array}$ \\
\hline Michigan & Coursera & $\begin{array}{l}\text { Engineering/ } \\
\text { Liberal Arts }\end{array}$ & unk & unk & unk & $\begin{array}{l}\text { computer sci- } \\
\text { ence to public } \\
\text { health to poet- } \\
\text { ry?; unk }\end{array}$ \\
\hline Duke & Coursera & $\begin{array}{l}\text { Engineering/ } \\
\text { Liberal Arts }\end{array}$ & unk & unk & unk & unk \\
\hline J. Hopkins & Coursera & $\begin{array}{l}\text { Engineering/ } \\
\text { Liberal Arts }\end{array}$ & unk & unk & unk & unk \\
\hline U. Virginia & Coursera & $\begin{array}{l}\text { Engineering/ } \\
\text { Liberal Arts }\end{array}$ & unk & unk & unk & unk \\
\hline
\end{tabular}

Evidently, the edX software, particularly the aspects that facilitate interactive learning, is still under development. This must be formidable challenge, considering the multitude of people that could avail themselves of this opportunity. Making this software development open source is understandable because it would seem that only the collaboration of competent and creative minds can make this functionality effective and ultimately successful.

Non-profit edX has some competition for free online courses from for-profit Coursera and Udacity, providers who are funded by venture capitalists. For now, at least, students can receive grades but, again, taking these courses will not count toward a degree.

... [In April 2012], Stanford, Princeton, Berkeley, the University of Pennsylvania and the University of Michigan announced that they were working with Coursera .... to put more than a dozen classes online [in 2012] in subjects ranging from computer science to public health to poetry. ... Coursera and Udacity, ... said they are committed to keeping their classes free and have each raised millions [of \$] from venture capitalists. ... .

Based on the above quote, one naturally wonders why venture capitalists are interested enough in free online learning to invest. Well, consider the possible rationale of providing student testing and certification services while charging for-profit fees, which is what some organizations such as Coursera have already started doing.

... As more people use [MOOCs (massive open online courses)] to assemble new educational pathways, the companies that provide them will likely turn to outside partners such as private testing firms to administer exams to large numbers of students, detaching assessment from colleges and universities. ... Still more external players may get involved in the credentialing process, such as state agencies or professional associations. ... the need to test enormous numbers of students could lead MOOC providers to develop standardized assessments that have the virtue of efficiency but the vice of narrowness. ${ }^{11}$ 
Based on the above quotes, the authors can now begin to see some of the profit motive behind venture capitalists that are supporting online education; and some potential dichotomies and/or downsides to online education.

The leaders of institutionalizing online learning, e.g., at MIT and Harvard, perhaps feel they have more than enough motivation for this endeavor. For example, eventually they may be able to charge for online courses and accumulate much more revenue than currently obtained from inclass tuition because of the volume of online students. Hypothetically, if one assumes that the number of online students is 100 times the number of in-class students, and that the charge per course is 10 times less, then the college/university makes 10 times the revenue offering online vs. in-class courses.

\section{Tier II Offerors}

The President of Boston's Suffolk University (a private and for-profit institution that started as a law school but has become more diversified, although they do not cover engineering) is now emphasizing online education. ${ }^{12}$ Another private institution that offers award winning online education is Stevens Institute of Technology in Hoboken, NJ. Stevens offers online courses for exactly the same cost as regular on-campus classes. ${ }^{13}$ However, this cost could possibly be reduced if Stevens can benefit from economies of scale.

There are other several entities, at least on the web, that provide online education, namely American Public University (APU) ${ }^{14}$ and Colorado Technical University (CTU), ${ }^{15}$ both presumably private and for-profit operations, and Northcentral University, a private and for-profit operation. $^{16}$

The Kaplan University, another presumably private and for-profit operation, web page offers no engineering degrees or certificates. However, they do promise other types. Students must pay approximately $\$ 22,000$ for a degree ${ }^{17}$ for a degree but Kaplan claims it costs less, and that Kaplan offers scholarships. ${ }^{18}$

Likewise, Capella University, also another presumably private and for-profit operation, offers no engineering degrees or certificates but promise other types. Evidently students must pay about $\$ 5,000$ per semester for online graduate $\operatorname{programs}^{19}$ but Capella offers what appear to be attractive scholarships. ${ }^{20}$

\section{Possible Abuses}

Here's a questionable example of online education by Western Oklahoma State College, a community college, that claims universities accept the credits for helping local members of the military and athletes maintain their NCAA eligibility. ${ }^{21}$ Two-week (10 day) classes costing $\$ 400$ each are offered. There are 30 online classes, microcomputer applications, create slide in PowerPoint, bake a cake (!), etc., apparently nothing really difficult, although the college touts each class as involving more work that a standard 16-week college course. This was to become under investigation by this college's accrediting body, which strikes one as hardly being a credible or unbiased investigation. Apparently other small colleges are offering similar online short-courses. 


\section{Functionalities of Online Learning}

Here are some existing and potential features (listed alphabetically) provided by online learning environments. ${ }^{8,22,23}$

- Blogging

- Certification

- Competition

- Cross-cultural interactions

- Electronic attendance lists

- Electronic publishing

- Electronic searches

- Grading

- Live meetings

- Meeting agendas

- Monitoring

- Quizzes

- Security protection

- Training

- Video tutorials

- Virtual laboratories

- Voting
- Broadcasting

- Collaboration

- Cooperation

- Discussion forums

- Electronic mailing lists

- Electronic resources

- Examinations

- Interactive design

- Live presentations

- Meeting minutes

- Prerecorded presentations

- Reviews

- Teleconferencing

- Video streaming

- Virtual chat rooms

- Voice streaming

- What if scenarios

To achieve their goals of online education, universities are currently either implementing or considering one of the following options.

1. Asynchronous: In this model, the lectures are pre-recorded and are viewed by and listened to by the student at any convenient time. Then they are expected to answer a series of questions based on the material reviewed. This is the most commonly used model for online education as it is easily implementable, and it gives faculty flexibility to "teach" from any location where they have an Internet connection.

2. Synchronous: In this model, the lectures are in real-time and can be accessed by all students participating at the same time, possibly with real time interactions through blogging or questions and answers. This model is less popular as faculty has to be available at the times that the real time interactions take place.

3. Hybrids: This model is a combination of online and in-class learning. Schools like California State University have started offering classes on campus one given week and online the next week. This way two classes can share just one classroom space during that semester, doubling space utilization.

\section{Pros and Cons of Online Education}

Some advantages and disadvantages of online education from a student's point-of-view are listed in Table 3. This could be viewed as a pair of lists that will evolve as we learn more. 
Table 3. Advantages and Disadvantages of Online Education to Students

\begin{tabular}{|c|c|}
\hline Advantage(s) & Disadvantage(s) \\
\hline Free; relatively low-bar, if any, for admission & No credible credential \\
\hline Credible Certificate & Some tuition required; must pass tests \\
\hline Credits toward degree & More tuition required; must pass tests \\
\hline Degree & $\begin{array}{l}\text { Admission requirements; considerable tuition } \\
\text { required; must pass exams }\end{array}$ \\
\hline Learn faster (at your best times and own speed) & May miss real-time interactions with others \\
\hline Save college commuting time & Miss social aspects of college life \\
\hline Greater authorities and experts are accessible & $\begin{array}{l}\text { May miss out on some works of on-campus } \\
\text { professors or teachers }\end{array}$ \\
\hline $\begin{array}{l}\text { More topics, subjects, and resources (through } \\
\text { Internet links) are available; more fun }\end{array}$ & $\begin{array}{l}\text { Less in-depth concentration than a highly tech- } \\
\text { nical and focused class, e.g., laboratory course }\end{array}$ \\
\hline $\begin{array}{l}\text { More interactions with teachers or professors } \\
\text { (depending on their dedication to online learn- } \\
\text { ing) and other students are possible than in- } \\
\text { class }\end{array}$ & $\begin{array}{l}\text { Teachers or professors may shirk duties most } \\
\text { conducive to online learning. Participants de- } \\
\text { termine what you contribute and how hard you } \\
\text { work (that could be advantageous, perhaps); } \\
\text { miss much in-class experience }\end{array}$ \\
\hline $\begin{array}{l}\text { Opportunity for making international contacts } \\
\text { and achieving collaborations (virtually) }\end{array}$ & $\begin{array}{l}\text { Risk of missing valuable personal relationships } \\
\text { potentially offered through in-class contacts }\end{array}$ \\
\hline $\begin{array}{l}\text { Draws on familiarity with social networks and } \\
\text { adeptness with personal communication and } \\
\text { gaming technologies }\end{array}$ & $\begin{array}{l}\text { Is more difficult (e.g., need to be able to work } \\
\text { independently; have good language, writing } \\
\text { and fast typing skills and manage time effec- } \\
\text { tively) and takes more time (typically } 9-12 \\
\text { hours per week per course) }\end{array}$ \\
\hline $\begin{array}{l}\text { Can work from home; military personnel can } \\
\text { still work on degree credits while continually } \\
\text { relocating to their new assignments }\end{array}$ & $\begin{array}{l}\text { Need equipage and web accesses: powerful } \\
\text { computer processor, printer, scanner, vid- } \\
\text { eo/graphics, various software packages, cyber } \\
\text { protections; web site access membership and } \\
\text { fees (e.g. to access E-library documents), etc. }\end{array}$ \\
\hline $\begin{array}{l}\text { Little or no loan debt upon completion of train- } \\
\text { ing (average college graduate's debt was } \\
\$ 27,000 \text { in 2011, up about } 50 \% \text { since 2001) }\end{array}$ & $\begin{array}{l}\text { Difficult to compete for jobs with college } \\
\text { graduates, especially those taking jobs not re- } \\
\text { quiring a degree }\end{array}$ \\
\hline $\begin{array}{l}\text { Greater potential for building career based on } \\
\text { high-capability skills society demands }\end{array}$ & $\begin{array}{l}\text { Relies on online education evolving in ways } \\
\text { that can outstrip benefits of college education }\end{array}$ \\
\hline
\end{tabular}

One of the reasons that online education is taking off and is projected to continue growing is because online courses require personal traits are already possessed by most students who are familiar with I-phones, texting, and social networks like Facebook, Twitter, Second Life, etc. On the other hand, online courses are not easy and generally demand more work than in-person courses - both for the student as well as for the faculty member teaching the class. ${ }^{22,24-31}$

This stimulates questions in the authors' minds about online versus college education in terms of achieving a successful career and life style. An article from the Boston Globe ${ }^{32}$ has a detailed table showing unemployment rate and earnings by education level, and a table showing median 
annual earnings of college graduates by bachelor's degree majors. Further, it discusses how graduates take more menial job opportunities away from those not getting college degrees. This raises a question whether online learners can turn this situation around, even if they only get completion certificates. This is an issue that the authors will continue to research.

Federal subsidies to universities for loans may be counterproductive and a hindrance to the development of online education because it keeps more students on campus, who could probably gain more from online education. Online education could possibly be more effective in creating job-qualified individuals; even compared to most who finish college. ${ }^{33}$

This suggests that U.S. online education should be shaped in ways that will encourage its evolution toward creating many more highly capable people with career abilities that cannot be duplicated by robots, at least for decades more. Online education would then have a great potential for closing the growing gap between the haves and the have-nots, even if low-skilled jobs disappear, and despite medium-skilled jobs being outsourced overseas. ${ }^{34}$

\section{Numbers of Online Students}

Even in 2012 the number of online students worldwide was in the millions. Many single courses attract tens to hundreds of thousands! ${ }^{3}$ Table 4 shows the large online course offerors, through whom millions of students get access to educational material that they otherwise would not be able to. ${ }^{4,10,25,35}$

Table 4. Number of Online Enrollees of Various Offerors ${ }^{3}$

\begin{tabular}{|c|c|l|}
\hline Online Offeror & Number of Enrollees & Comment \\
\hline Coursera & 1.5 million & \\
\hline edX & 155,000 & Spring 2012 class only \\
\hline Udacity & 739,000 & \\
\hline Open Learning Initiative & 51,000 & \\
\hline University of Phoenix & 346,000 & \\
\hline The Open University & 264,000 & \\
\hline
\end{tabular}

It is evident that the number of online students is steadily increasing. There were about 6.1 million online students in 2010 and this number is expected to rise to about 12 million by 2014 and to 22 million by $2017-18,{ }^{27,30,36}$ thus showing a tremendous opportunity for work to be done in this area.

\section{Innovation From Online Learning Environment}

According to the MIT Technology Review, ${ }^{3}$ the effectiveness of student learning can vary depending on the mode of receiving information. The Internet has made possible massive amounts of online learning as well as changed the way education is imparted to students. It is more about the students asking questions, rather than the teachers. Students are then more motivated to revisit the topics and see responses to their queries. ${ }^{24}$ 
Furthermore, online learning is self-tailorable to a student's needs. ${ }^{24}$ Learning will become learner focused, real-time problem posing and solving, discussion of case studies, in-class (online) homework, more interactive, clicker (voting) based with teacher oversight, questions from students, i.e., "flipping the classroom", ${ }^{37}$ less lecture, homework oriented more to absorbing lecture material, on-line video instruction, etc. ${ }^{17}$

Traditional lecture teaching will decline because information transfer can be done more effectively online. Most learning in-person will be very different from in-person learning today. In person, or face-to-face (F2F), learning will be focused around what the Internet cannot do. It will be oriented around the integrational aspects of learning. It will be learnercentered. $^{24}$

Familiarity with computers, personal phones and related technologies, the Internet, social media, and videos are among the most important factors that stimulate online learning. ${ }^{38}$

As previously mentioned one needs good language and communications skills to be a successful online learner as well as teacher. This need was made clear by virtue of a posting that appeared in the American Society for Engineering Education (ASEE) magazine. ${ }^{39}$

The authors are beginning to understand how well online education actually does in facilitating learning.

... a comprehensive 2009 look at online learning by the [U.S.] Department of Education found that college students who took some or all of their courses online performed "modestly better" than those who took the same courses in a face-to-face setting. The advantages were even bigger for "blended learning, "courses that combine online instruction with some face-to-face time". 28

An example of children in Ethiopia teaching themselves to use tablet computers in a project that aims to test the effectiveness of self-instruction ${ }^{40}$ supports what should be an almost obvious insight that children can learn much on their own because they naturally "get" complexity at an early age. Thus it could lead to high effectiveness in online education as well to this younger generation.

Many of the rules of etiquette for online learning carry over from good face-to-face and no stabbing-in-the back behind-the-back behaviors. Netiquette, or Internet etiquette, are guidelines for posting and sending messages in the online classroom ${ }^{22 .}$.

\section{Legitimate Credentialing}

Free online courses cannot be taken for credit. However, on edX a certificate of completion can be obtained for a modest fee. ${ }^{41}$ With Coursera and Udacity, students can receive grades but, again, taking these courses will not count toward a degree. ${ }^{9}$

Considering the growing demand for information and thus education, "students press providers to offer degrees or other formal validation of the knowledge and skills they've acquired. Still 
more external players may get involved in the credentialing process, such as state agencies or professional associations."

Due to this increasing demand and limited resources, certificates may not be free in the future, however. [Berkeley] is considering whether to charge a small fee that could vary depending on students' means."

\section{Impacts on Colleges and Universities}

The long term impact will be interesting in terms of researching how universities enhance their understanding of how people learn through online education and how students can be graded, especially through evaluations that don't require relatively simple scoring techniques from multiple choice tests, for example. ${ }^{35}$

Online education could greatly affect how colleges offer higher education, particularly at the graduate level. ${ }^{11}$ Universities such as the California State University system are giving a greater focus to online education and are moving in the direction of offering a significantly larger number of their graduate classes online and concentrating more on undergraduate education, when it comes to traditional on-campus learning.

The online courses may pose a serious challenge to the way institutions deliver a college education. ... With millions of dollars in funding and the backing of some of the nation's elite institutions, [online courses are] forcing colleges and policymakers to rethink higher education. ... [MOCC] have changed the whole notion of college access and affordability. ... ${ }^{25}$. [Additionally,] private testing firms to administer exams to large numbers of students [have starting springing up], [thus] detaching assessment from colleges and universities. Next, credentialing could also be separated from colleges as well .... ${ }^{11}$

\section{Conclusion and Future Work}

Online education, though amazingly popular (cf., the student advantages and disadvantages summarized in Table 3 of this paper), drawing huge numbers of students and interesting many teachers and professors, based upon the authors' research so far, is still in its infancy. None of the many free on-line courses offered by elite institutions - or anyone else - leads to college degrees, neither college credit toward degrees nor sufficiently credible certificates of completion. However, there has been significant progress toward obtaining more credible certificates of completion - or even degrees - if one pays some tuition and passes suitably proctored tests or examinations. The amount of tuition necessary appears to be generally proportional to the credibility of the certificate and/or degree. Some online programs charge even more tuition than the in-class college equivalents. However, further data needs to be gathered before more comprehensive cost scenarios can be presented. An additional source of interest was just added (in proof). ${ }^{42}$

There is the potential for online education to continue to blossom in at least two areas: 1) many more people can become well-trained for productive careers benefiting society at much lower cost compared to attending college; and 2) colleges and universities will be able to reap more revenue by harnessing the economies of scale of many more online students even while charging 
much less tuition per student. Those days are not here yet, but these possibilities may be already foreseen by college administrators and venture capitalists. Why else would there be so much investment in online education?

As part of future offerings in online education, we will see an increasing number of universities start adopting this model of education due to the many benefits associated with it, especially for current generations of students who are already used to the requisite social networking and technological aspects associated with online learning. Academics also speculate that there could be a significant increase in the amount of research done to address the issues currently affecting online education.

Course development can be significantly enhanced when implementing online education. This is because collaborative efforts can be made between subject matter experts in certain areas to design related courses. As a result, the courses being offered can be developed jointly, thus giving the students different perspectives on the subject matter. A similar approach can also be taken to teaching online courses. Courses could be taught by subject matter experts remotely and hence the students could have access to a much more qualified pool of faculty, thus resulting in a much better overall learning experience.

The authors would like to point out that this is work in progress and is part of a much larger research initiative. This paper has only scratched the surface in presenting the state of online education and its prospects for the future. Next the authors plan to research online education costbenefit trade-offs for professors and teachers. To this end a survey of the faculty at various schools where the authors have contacts, like California State University, Salem State University, MIT, Stevens Institute of Technology, U.S. Military Academy, University of North Texas, University of Adelaide, and Baruch College of the City College of New York, will be conducted. Another topic for a future paper is comprehensive coverage of the broad array subject domain programs.

The authors will continue researching and analyzing available data of colleges and universities, as they revamp their strategies, policies, practices, and operations to better accommodate online learning. The authors conclude that online vs. in-class education is not an either-or proposition. Together these two modes will continue to coexist with the likelihood that hybrid combinations that strengthen the overall posture of higher education will continue to improve and ultimately thrive and emerge as the preferred choice.

\section{Bibliography}

1. California State University, Northridge (CSUN), 2012, http://tsengcollege.csun.edu/programs/online.

2. Kelsey Sheehey, http://www.usnews.com/education/online-education/articles/2012/01/10/us-news-ranks-toponline-degree-programs.

3. Nicholas Carr, "The Crisis in Higher Education," MIT Technology Review, Vol. 115, No. 6, November/December 2012, e.g., p. 34-36,38.

4. National Public Radio (NPR), 30 September 2012, http://www.npr.org/2012/09/30/162053927/online-educationgrows-up-and-for-now-its-free. 
5. “Georgetown joins venture to provide courses worldwide," The Boston Globe, Friday, 16 December 2012, p. A14.

6. Washington Post, 9 December 2012, http://www.washingtonpost.com/local/education/georgetown-to-offer-freeonline-courses/2012/12/09/365c4612-3fd3-11e2-bca3-aadc9b7e29c5_print.html.

7. Education News, http://www.educationnews.org/online-schools/wellesley-college-is-first-liberal-arts-school-tojoin-edx/.

8. Peter Schworm, "Liberal arts get online tryout," The Boston Globe, Tuesday, 4 December 2012, pp. B1, B4.

9. National Public $\quad$ Radio $\quad$ (NPR), 49 May http://www.npr.org/blogs/alltechconsidered/2012/05/09/151876426/explosion-in-free-online-classes-maychange-course-of-higher-education.

10. Werthmann, Melissa M., "Calif. University joins Harvard, MIT venture," The Boston Globe, Tuesday, 24 July 2012, pp. B1, B4.

11. Aoun, Joseph E. "The MOOC effect," The Boston Globe, Saturday, 17 November 2012, e.g., p. A9.

12. Martine Powers, "Suffolk to stress career learning," The Boston Globe, Tuesday, 4 December 2012, pp. A1, A20.

13. Stevens Institute of Technology, http://www.webcampus.stevens.edu/tuition-fees.aspx.

14. American Public University, http://www.apu.apus.edu/.

15. Colorado Technical University, http://online.coloradotech.edu/CTU/OnlineEducation/Home/?code $=4692 \&$ vid $=543 \&$ src $=$.

16. Northcentral University, http://education.ncu.edu/.

17. The Diane Rehm Show, http://thedianerehmshow.org/shows/2012-10-03/salman-khan-one-world-schoolhouseedu.

18. Kaplan University, http://getinfo.kaplan.edu/.

19.

Capella

University, https://portal.capella.edu/psp/pa89prd/CAPELLA/CU PUBLIC/s/WEBLIB IS AW.ISCRIPT1.FieldFormula.I Script_AssemblePage?AWGroupID=CU_FINANCIAL_AID_PLANNER\&AWPageID=CU_APPLY_TO_CA PELLA\&AWObjName=CU_APPLY_TO_CAPELLA0.

20. Capella University, http://info.capellauniversityonline.com/.

21. Chronicle, http://chronicle.com/blogs/players/category/western-oklahoma-state-college.

22. O'Neil, Carol A., Cheryl A. Fisher, and Susan K. Newbold, Developing an Online Course -- Best Practices for Nurse Educators, Springer Series on The Teaching of Nursing, New York: Springer, 2004, pp. x, 15, 103, $107-$ 109.

23. Paul Flanagan, "Online vs. on campus," in MIT Technology Review, Vol. 115, No. 6, November/December 2012, MIT News, Alumni Letters, p. 3.

24. Draves, William A., Teaching Online, 2nd Edition, LERN Books, River Falls, WI, 2002, e.g., pp. $4,8,9,11,15,63.64,97,98$. 
25. National Public Radio (NPR), 4 December 2012, http://www.npr.org/2012/12/04/166470215/online-coursesforce-changes-to-higher-education).

26. Dale Kirby, Dennis B. Sharpe, and Michael K. Barbour, "Student Perceptions and Preferences for Tertiary Online Courses: Does Prior High School Distance Learning Make a Difference?," teaching.uncc.edu/articlesbooks/tip-sheets/student-perceptions.

27. Kristin DeAngelis, "Online Learning: Student Perceptions," University of North Carolina (UNC) Charlotte Center for Teaching and Learning, March 2009, https: //teaching.uncc.edu/sites/teachinguncc.edu/files/OnlineLearningStudentPerceptionsTipSheet.pdf.

28. "Online classes in schools aren't just a way to save money," Editorial, The Boston Globe, Wednesday, 19 December 2012, p. A18.

29. Sener Learning, http://www.senerlearning.com/blogs/npr-reports-online-education.

30. D. C. Denison, “Are you ready for online learning?," The Boston Globe, Sunday, 7 October 2012, pp. G1, G5.

31. National Public Radio (NPR), http://www.npr.org/templates/story/story.php?storyId=16638700.

32. Jay Fitzgerald, "A college degree is costly, but it pays off over time," The Boston Globe, Sunday, 7 October 2012.

33. Megan McArdle, "The College Bubble--Why are we spending so much money on college?," Newsweek, 17 September 2012, pp. 22-26.

34. James Case, Competition--The Birth of a New Science, New York: Hill and Wang, 2007, pp. 308-311.

35. Brock Parker, "Harvard draws a crowd online," The Boston Globe, Monday, 15 October 2012, pp. B1, B4.

36. Education http://www.educationconnection.com/onlinecol-

lege3?CID=ppcgoogleheadtermPremierC\&key=go_online_colleges_exact\&v=google\&a=mcsansaroli\%2Bgene ric\%40educationconnection.com\&c=Head+Terms $+2011 \& c a t=$ online_colleges_exact\&mt $=$ search\&ad=9681154 926\&est=online $\% 20$ colleges\&emt=Exact \&bucket=google-search-text-generic-ecs\&trackid=google-search-textgeneric-ecs\&gclid=CPeWk5SRgbQCFY-d4Aod0E0AmQ.

37. "Flip teaching," Wikipedia, The Free Encyclopedia, http://en.wikipedia.org/wiki/Flip teaching.

38. Matthew W. Liberatore, Andrew W. Herring, and Charles R. Vestal, "Online in Reverse--Students generate and solve problems based on videos they select," Prism, American Society for Engineering Education (ASEE), Vol. 22, No. 3, November 2012, p. 045.

39. Prism, American Society for Engineering Education (ASEE), Vol. 22, No. 3, November 2012, p. 009.

40. Nicholas Negroponte, “Another Way to Think about Learning," MIT Technology Review, Vol. 115, No. 6, November/December 2012, p. 37.

41. edX, Wikipedia, The Free Encyclopedia, http://en.wikipedia.org/wiki/EdX.

42. Amanda Ripley, "Reinventing College,” Time, Vol. 180, No. 18, 29 October 2012, pp. 31-41. 